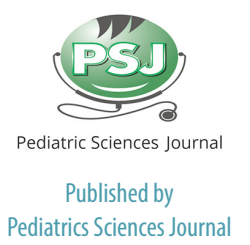

Pediatrics Sciences Journal

\section{Screening for congenital hypothyroidism in Malang, East Java in 2020}

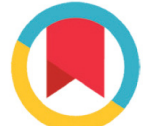

CrossMark

\author{
Irfan Agus Salim 1*, Berlian Ristina Putri', Tiara Afia Rosmalawati', \\ Haryudi Aji Cahyono ${ }^{1}$, Fadhilah Muttaqin ${ }^{1}$
}

${ }^{1}$ Child Department, Faculty of Medicine, Universitas Brawijaya, Dr. Saiful Anwar Regional Public Hospital, Malang, Indonesia
*Corresponding to: Irfan Agus Salim; Child Department, Faculty of Medicine, Universitas Brawijaya, Dr. Saiful Anwar Regional Public Hospital, Malang, Indonesia; irfanaqus.fk@ub.ac.id

\section{ABSTRACT}

Introduction: Congenital hypothyroidism is defined as a state of thyroid hormone deficiency present at birth. Congenital hypothyroidism must be diagnosed immediately because delay in therapy may cause irreversible neurological deficits, such as mental retardation in children. However, this condition can be prevented by screening in newborns so that congenital hypothyroidism can be diagnosed and treated early, and can result in better neurological development. This study aims to determine the congenital hypothyroidism ratio in Malang from March to November 2020.

Methods: The descriptive analysis method was used in this research. The subjects were neonates aged $0-28$ days with a gestational age of 36 weeks and were involving the Health Office in both the Regency and the City of Malang. The data about identity, gender, age at screening, and gestational age were collected. A laboratory screening test was performed by taking a blood sample from the heel or vein for a TSH test. If the result was positive with a TSH value $>20 \mathrm{U} / \mathrm{mL}$, the subject would be recalled for having a confirmation test and referred to a pediatric endocrinologist.

Results: There were 2024 (88.34\%) subjects were successfully screened from a total of 2291 subjects. The recall rate for congenital hypothyroidism was 1:2024 (0.04\%).

Conclusion: The ratio of congenital hypothyroidism cases in Malang from March to November 2020 was higher than the global ratio, which was 1:3000. The high rate of congenital hypothyroidism in Malang indicated the need for congenital hypothyroidism screening in newborns.
Received: 2021-10-21

Accepted: 2021-11-28

Published: 2021-12-05
Keywords: congenital hypothyroid screening, Malang, East Java, 2020.

Cite This Article: Salim, I.A., Putri, B.R., Rosmalawati, T.A., Cahyono, H.A., Muttagin, F. 2021. Screening for congenital hypothyroidism in Malang, East Java in 2020. Pediatrics Sciences Journal 2(2): 38-43.

\section{INTRODUCTION}

Congenital hypothyroidism is a state of thyroid hormone deficiency present at birth. Congenital hypothyroidism must be diagnosed immediately because delay in therapy may cause irreversible neurological deficits, such as mental retardation in children. However, this condition can be prevented by doing a screening in order to establish early diagnosis and treatment and result in better neurological development. Thyroid hormones play an important role in energy metabolism, growth, and neurodevelopment. In particular, thyroid hormone acts on neuron differentiation, synapse development, and myelination in the prenatal and newborn periods, regulates the development of the central nervous system. A laboratory screening test is performed by taking a blood sample for a TSH test. A TSH level above $20 \mathrm{U} /$ $\mathrm{mL}$ is used as a cutoff which requires a confirmation test using a serum sample to confirm the diagnosis of congenital hypothyroidism. ${ }^{1}$

Globally, congenital hypothyroidism is estimated at approximately 1:3000 births with a very high incidence in areas of iodine deficiency, namely 1:900. Congenital hypothyroidism is more common in girls than boys in a 2:1 ratio. The incidence of congenital hypothyroidism varies between countries, several factors that influence are racial and ethnic factors. Prevalence tends to be higher in Asian descent and less common in the black population. ${ }^{1}$

There are 11 provinces in Indonesia, from 2000 to 2013199,708 babies were screened with a high result of 73 cases (1:2736). This ratio is higher than the global ratio, which is $1: 3000$ births. If it is assumed that the ratio of the incidence of congenital hypothyroidism is 1:3000 with a projected birth rate of 5 million babies per year, it is estimated that more than 1600 babies with congenital hypothyroidism will be born each year. ${ }^{2}$ Referring to the ratio of congenital hypothyroidism incidence in Indonesia which is higher than the global ratio, it is necessary to hold a routine screening of congenital hypothyroidism in newborns, in accordance with the Regulation of the Minister of Health of the Republic of Indonesia No. 78 Years 2014 on Congenital Hypothyroid Screening. This research aimed to determine the ratio of congenital hypothyroidism in Malang in 2020 .

\section{METHOD}

This research used a descriptive analysis method which was held in Malang, consisted of 20 hospitals, 6 community health centers, and 25 independent midwife practices (PBM) from March to November 2020. 
All newborns 0-28 days old with gestational age 36 weeks participated in this research. There was a sampling error so that it did not meet the requirements to be rejected from the research. Identity, gender, age at sampling, and gestational age were recorded. Sampling was taken from the heel or vein by a doctor or midwife before leaving the hospital, Puskesmas or independent midwifery practice (PBM). Blood spots on filter paper need at least 5-6 hours to dry. The dried blood spot samples were transported within 24 hours to the nearest standard laboratory. The sample tested is the value of ThyrotropinStimulating Hormone (TSH). The TSH limit value for screening for congenital hypothyroidism is $20 \mathrm{U} / \mathrm{mL}$.

Parents whose children had positive screening results were contacted by hospital staff for a confirmation blood serum sample test. Congenital hypothyroidism is confirmed when serum TSH is elevated $(>20 \mathrm{U} / \mathrm{mL})$ and free T4 is decreased. All patients were tested under the supervision of a pediatric endocrinologist, patients with positive confirmation test results were referred to a pediatric endocrinologist for treatment and follow-up. Data were analyzed using excel version 16.51 .

\section{RESULTS}

A total of 2291 newborns from hospitals, health centers, and independent midwife practices in Malang in 2020 were screened for hypothyroidism. Screening samples are taken from the heel or vein. Of this total, only $2024(88.34 \%)$ could be screened for the measurement of TSH values. In the group tested for TSH values, 1010 (49.91\%) were male and 1014 (50.09\%) were female, with a male to female ratio of 1:1.004. The characteristics of the subjects and the results of this research can be seen in Table 1.

One newborn was found positive after TSH screening with a TSH value of $19.52 \mathrm{U} / \mathrm{mL}$ in April. This patient was successfully recalled and underwent a confirmation test with an FT4 level test. The FT4 result was $0.75 \mathrm{pmol} / \mathrm{L}$ which indicated that the FT4 level had decreased. Thus, it can be concluded that the patient is congenitally positive for hypothyroidism. The patient was then referred to a pediatric

Table 1. Basic Characteristics of Study Subjects

Characteristics

Number of screened babies ( $n$ )

Succeed

Rejected

Gender, $\mathbf{n}(\%)$

Male

Female

Sampling Age (days)

Confirmation positive (n)

Recall rate (ratio)
Congenital Hypothyroid Screening

2291

2024

267

$1010(49.91)$

$1014(50.09)$

2 days (0-28 days)

1

$1: 2024$

Table 2. Average TSH Levels in Malang Years 2020

\begin{tabular}{ccc}
\hline Months & $\begin{array}{c}\text { Average TSH Level } \\
(\boldsymbol{\mu U} \mathbf{m L})\end{array}$ & $\begin{array}{c}\text { Congenital Hypothyroid Positive } \\
\text { Number }\end{array}$ \\
\hline March & 1.773 & 0 \\
April & 2.019 & 1 \\
May & 1.896 & 0 \\
June & 1.988 & 0 \\
July & 2.020 & 0 \\
August & 2.614 & 0 \\
September & 1.844 & 0 \\
October & 1.870 & 0 \\
November & 1.272 & 0 \\
Total average & $\mathbf{1 , 9 1 3}$ & $\mathbf{1}$ \\
\hline
\end{tabular}

endocrinologist for treatment and further action. The average TSH levels obtained from this research and the distribution of subjects who were positively screened can be seen in Table 2.

\section{DISCUSSION}

Indonesia accommodated 270.20 million people in 2020. In 2010-2020, demographic trends showed an increase in population growth and life expectancy, as well as a decrease in infant mortality. Indonesia does not yet have national data, there are only a few data, such as from RSCM Jakarta which screened for congenital hypothyroidism from 2000 to September 2014. The results of the screening showed 85 positive babies out of 213,669 babies with a ratio of 1:2513 births. It is seen that this figure is higher than the global prevalence which was at 1:3000 births. ${ }^{3}$
The second is data from RSHS Bandung obtained from a review of medical records at an endocrine clinic that $70 \%$ of infants diagnosed with congenital hypothyroidism were more than 1 year old and $2.3 \%$ were diagnosed under 3 months of age. $2.3 \%$ of these infants had minimal growth and developmental retardation, while the other $70 \%$ had permanent mental retardation. ${ }^{4}$

Based on data collected by the Pediatric Endocrinology UKK from several hospitals in Jakarta, Bandung, Yogyakarta, Palembang, Medan, Banjarmasin, Solo, Surabaya, Malang, Denpasar, Makassar, and Manado, it was found that 595 cases of congenital hypothyroidism were treated during $2010 .^{2}$

Congenital hypothyroidism cases internationally, the prevalence in the Japanese is 1:7600, whereas in the black population it is very rare. The prevalence 
of congenital hypothyroidism in the UK shows a higher incidence in children of Asian descent. In Asian countries, the incidence in Singapore is 1:3000-3500, Malaysia is $1: 3026$, the Philippines is $1: 3460$, Hong Kong is 1:240. The incidence is lower in Korea 1:4300 and Vietnam 1:5502. Preliminary projects in India show a higher incidence of 1:700 and in Bangladesh 1:20000. 2

Congenital hypothyroidism cases throughout Indonesia based on the IDAI Registry as of August 2015 there were 680 cases. Based on data from the Endocrinology Polyclinic, Department of Pediatrics, RSCM from January 2005 to November 2011, 162 new cases of congenital hypothyroidism were found. Data obtained from the results of the "1000 Congenital Hypothyroid Screening Babies" program conducted at the Perinatology section of the Department of Pediatrics, RSCM, found 4 babies with congenital hypothyroidism detected from 1000 babies examined.

Based on the results of the 2018 Basic Health Research report, it was found that the proportion of CHS examinations was still very low, which was only $4.6 \%$ for the total proportion of CHS in Indonesia. The data showed that DI Yogyakarta Province is the area with the highest proportion of CHS examinations, as many as $14.6 \%$, and the lowest is North Sumatra Province with the proportion of CHS examinations being only $1.7 \%$. For East Java Province, it reached $4.4 \%$, the lowest of all provinces in Java. ${ }^{6}$

Therefore, the burden of noncommunicable diseases is expected to increase, thereby doubling the disease burden. Congenital hypothyroidism is the most common endocrine disease in newborns detected through newborn screening.

Congenital hypothyroidism is a condition of decreased or nonfunctioning thyroid gland that is present at birth. This occurs due to anatomic abnormalities or metabolic disorders of thyroid hormone formation or iodine deficiency. ${ }^{2,7}$ There are two major classifications of causes of congenital hypothyroidism, namely permanent and transient congenital hypothyroidism. The etiology of permanent congenital
Table 3. The proportion of Congenital Hypothyroid Screening (CHS) at Birth in Children aged 0-59 Months by Province ${ }^{6}$

\begin{tabular}{|c|c|c|c|c|c|c|}
\hline \multirow{2}{*}{ Province } & \multicolumn{2}{|c|}{ Examined } & \multirow{2}{*}{$\begin{array}{c}\text { Not } \\
\text { examined }\end{array}$} & \multirow{2}{*}{$\begin{array}{c}\text { Not } \\
\text { applicable }\end{array}$} & \multirow{2}{*}{$\begin{array}{l}\text { Did not } \\
\text { know }\end{array}$} & \multirow[t]{2}{*}{$\mathbf{N}$} \\
\hline & $\%$ & $95 \% \mathrm{Cl}$ & & & & \\
\hline Aceh & 3.2 & $2.4-4.2$ & 61.2 & 6.8 & 28.8 & 2.199 \\
\hline $\begin{array}{l}\text { Sumatera } \\
\text { North }\end{array}$ & 1.7 & $1.2-2.5$ & 65.5 & 2.7 & 30.1 & 5.736 \\
\hline $\begin{array}{l}\text { Sumatera } \\
\text { West }\end{array}$ & 5.5 & $4.7-6.5$ & 71.3 & 0.8 & 22.4 & 2.158 \\
\hline Riau & 1.9 & $1.3-2.6$ & 77.7 & 0.9 & 19.5 & 2.768 \\
\hline Jambi & 4.4 & $3.3-5.9$ & 63.2 & 2.3 & 30.1 & 1.256 \\
\hline $\begin{array}{l}\text { Sumatera } \\
\text { South }\end{array}$ & 4.0 & $3.1-5.2$ & 65.5 & 3.1 & 27.5 & 2.961 \\
\hline Bengkulu & 3.3 & $2.3-4.5$ & 61.0 & 6.5 & 29.3 & 705 \\
\hline Lampung & 2.5 & $1.9-3.3$ & 68.7 & 3.3 & 25.5 & 3.051 \\
\hline $\begin{array}{l}\text { Bangka } \\
\text { Belitung }\end{array}$ & 2.7 & $1.7-4.1$ & 69.3 & 5.4 & 22.7 & 522 \\
\hline Riau islands & 5.1 & $3.4-7.4$ & 59.5 & 1.7 & 33.7 & 861 \\
\hline DKI Jakarta & 12.3 & $10.0-14.9$ & 54.4 & 0.8 & 32.5 & 3.559 \\
\hline West Java & 5.4 & $4.7-6.3$ & 61.5 & 2.9 & 30.2 & 16.883 \\
\hline Central Java & 5.1 & $4.5-5.8$ & 59.7 & 2.4 & 32.9 & 10.446 \\
\hline Yogyakarta & 14.6 & $11.4-18.6$ & 60.4 & 0.4 & 24.6 & 1.062 \\
\hline East Java & 4.4 & $3.7-5.1$ & 61.3 & 2.7 & 31.6 & 11.177 \\
\hline Banten & 5.8 & $4.6-7.4$ & 67.4 & 2.0 & 24.8 & 4.702 \\
\hline Bali & 5.2 & $4.0-6.7$ & 67.3 & 0.5 & 27.1 & 1.269 \\
\hline $\begin{array}{c}\text { West Nusa } \\
\text { Tenggara }\end{array}$ & 3.4 & $2.4-4.7$ & 70.1 & 3.2 & 23.3 & 1.965 \\
\hline $\begin{array}{l}\text { East Nusa } \\
\text { Tenggara }\end{array}$ & 4.3 & $3.5-5.3$ & 65.7 & 2.9 & 27.1 & 2.402 \\
\hline $\begin{array}{c}\text { West } \\
\text { Kalimantan }\end{array}$ & 3.4 & $2.5-4.6$ & 64.7 & 8.0 & 23.9 & 1.841 \\
\hline $\begin{array}{c}\text { Central } \\
\text { Kalimantan }\end{array}$ & 2.6 & $1.9-3.6$ & 62.8 & 6.8 & 27.8 & 947 \\
\hline $\begin{array}{c}\text { South } \\
\text { Kalimantan }\end{array}$ & 3.1 & $2.1-4.7$ & 69.5 & 2.7 & 24.7 & 1.546 \\
\hline $\begin{array}{c}\text { East } \\
\text { Kalimantan }\end{array}$ & 2.3 & $1.5-3.4$ & 66.4 & 4.2 & 27.1 & 1.344 \\
\hline $\begin{array}{c}\text { North } \\
\text { Kalimantan }\end{array}$ & 3.7 & $2.3-5.8$ & 69.1 & 1.2 & 26.0 & 306 \\
\hline $\begin{array}{c}\text { North } \\
\text { Sulawesi }\end{array}$ & 7.5 & $6.0-9.4$ & 56.8 & 2.7 & 33.0 & 807 \\
\hline $\begin{array}{l}\text { Central } \\
\text { Sulawesi }\end{array}$ & 3.3 & $2.5-4.4$ & 71.8 & 1.7 & 23.2 & 1.138 \\
\hline $\begin{array}{c}\text { South } \\
\text { Sulawesi }\end{array}$ & 3.4 & $2.6-4.3$ & 56.9 & 2.2 & 37.6 & 3.158 \\
\hline $\begin{array}{l}\text { Southeast } \\
\text { Sulawesi }\end{array}$ & 2.1 & $1.4-3.1$ & 75.6 & 2.5 & 19.8 & 1.121 \\
\hline
\end{tabular}


hypothyroidism is thyroid dysgenesis (80-85\%), dyshormonogenesis (15-20\%), hypothalamic-pituitary axis dysfunction, and resistance to thyroid hormones. While the etiology of congenital hypothyroidism is transient $(<5 \%)$, namely iodine deficiency, iatrogenic due to intrauterine exposure to goitrogen substances (anti-thyroid drugs, iodine, maternal antibodies, idiopathic), immaturity of the hypothalamic-pituitary-thyroid axis due to prematurity, infection, or stress conditions.?

Most newborns with congenital hypothyroidism have no obvious clinical signs and symptoms. Only 5 to $10 \%$ of them show symptomatic manifestations at birth or soon after birth. The majority of newborns will appear normal and healthy so doctors may not suspect they have congenital hypothyroidism. ${ }^{8,9}$

Some things that can be noticed in infants with congenital hypothyroidism, namely in newborns up to the age of 8 weeks of non-specific complaints, developmental retardation, failure to thrive or short stature, lethargy, inactivity, constipation, lazy sucking, hoarse crying voice, pale, baby born in an area with a prevalence of endemic cretinism and an area of iodine deficiency, premature birth or more months (postmature), a family history of thyroid disorders, maternal illness during pregnancy, currently taking antithyroid drugs, and light therapy. Clinical manifestations that can be seen in congenital hypothyroidism include a large fontanelle or late closing, dull face, macroglossia, dry skin, umbilical hernia, mottling, cutis marmorata, decreased activity, jaundice, hypotonia, at first glance like Down's syndrome, but at a glance Down syndrome babies are more active, more common in infants with birth weight less than $2000 \mathrm{~g}$ or more than 4000 g, about $3-7 \%$ of infants with congenital hypothyroidism are usually accompanied by other congenital abnormalities, especially atrial and ventricular septal defects. $^{\text {? }}$

Babies with congenital hypothyroidism may have difficulty feeding and become constipated. If left untreated, congenital hypothyroidism can lead to complications, namely intellectual disability and slowed growth. ${ }^{10}$ There is an increased incidence

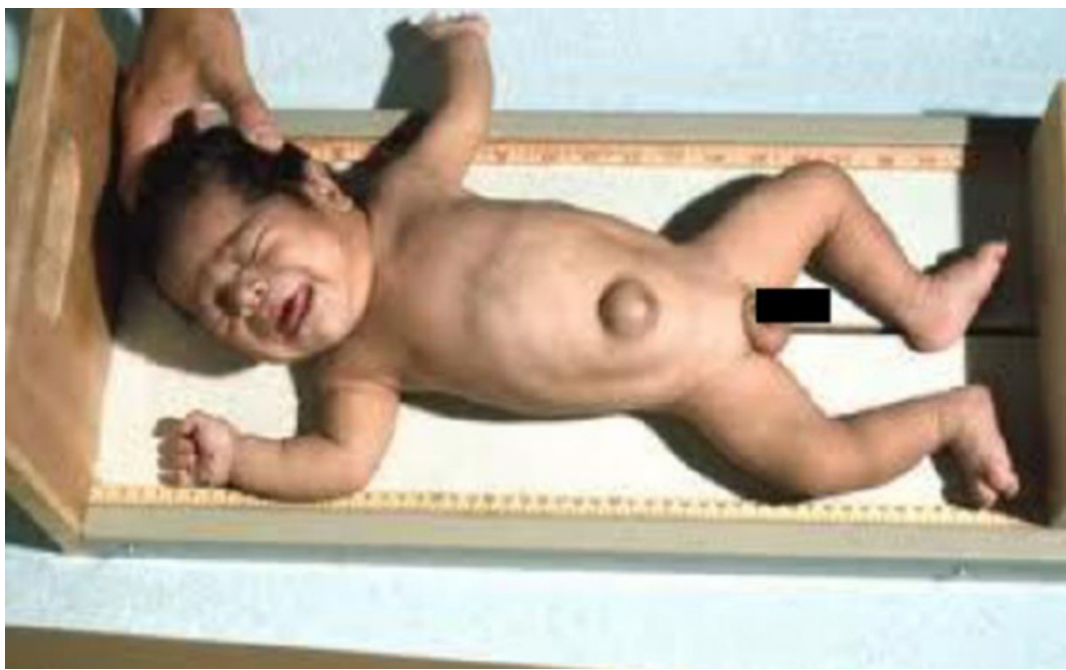

Figure 1. Infants with symptoms of congenital hypothyroidism: macroglossia, umbilical hernia, dry scaly skin, scrotal edema. ${ }^{2}$

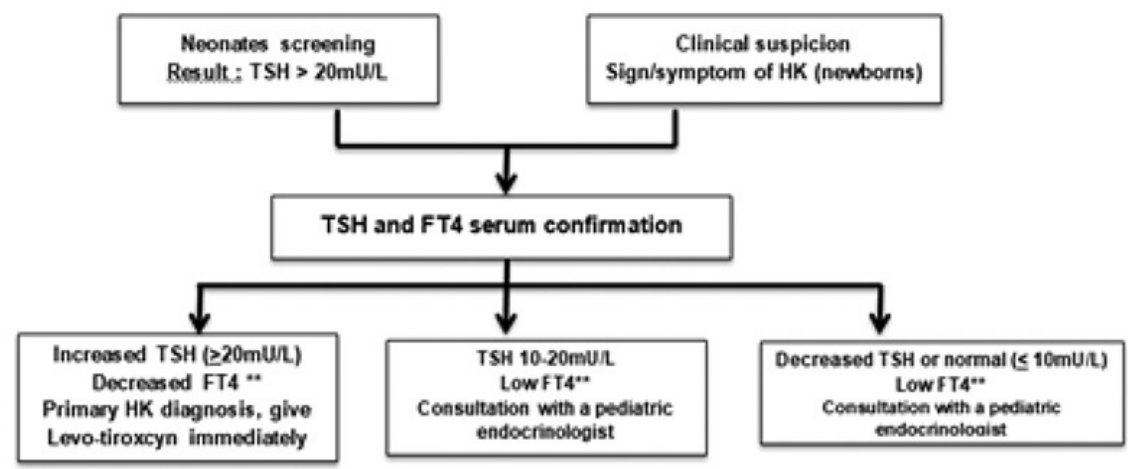

Figure 2. The diagnostic flow of congenital hypothyroidism. ${ }^{2}$

${ }^{*}$ For those who are not willing to undergo an FT4 examination, a T4 examination can be performed

${ }^{* *}$ low below normal or laboratory standards for age
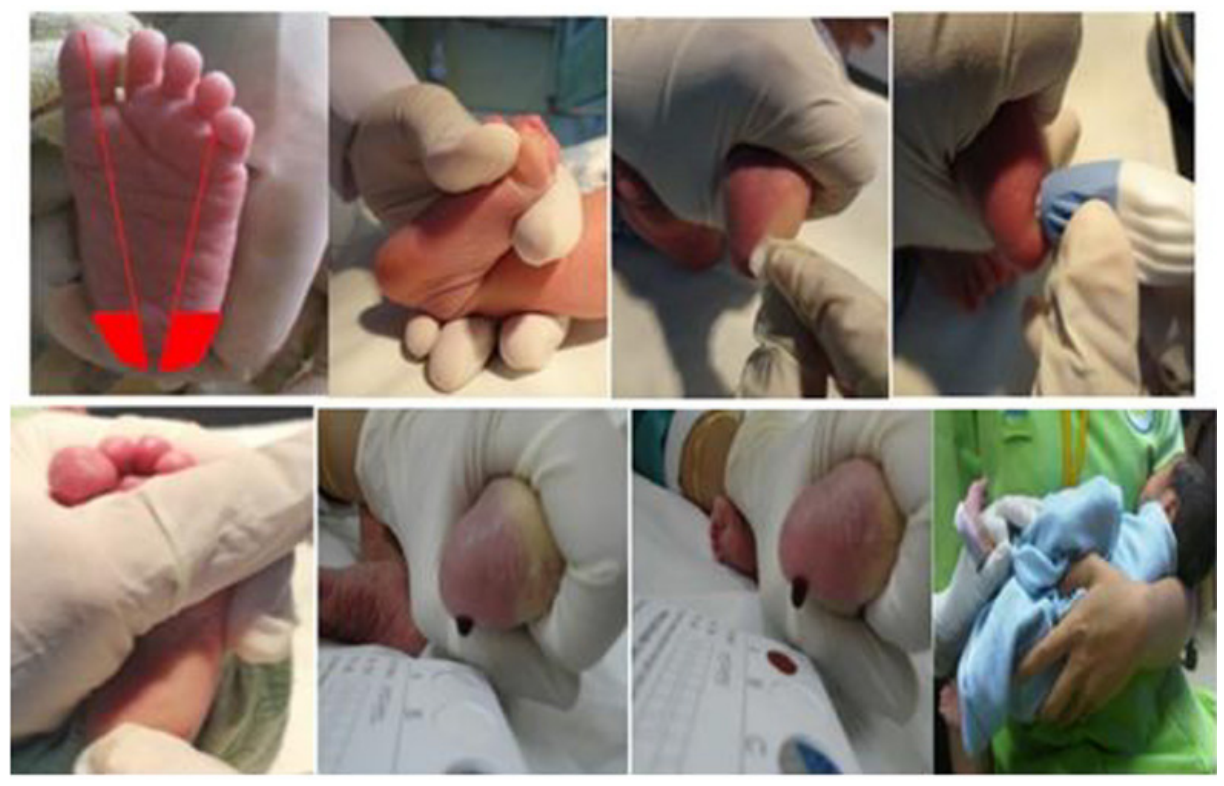

Figure 3. Sampling procedure for screening for congenital hypothyroidism. ${ }^{2}$ 
of other congenital malformations in children with congenital hypothyroidism, particularly cardiac malformations, including septal defects, kidney disorders, and the risk of developmental disorders. nerve. A thorough clinical examination should be performed, including a hearing examination. ${ }^{11}$

Congenital hypothyroidism has a very good prognosis if it is detected and treated early. Giving the best medical therapy in infants aged $<2$ weeks. Delay in giving therapy can lead to a greater risk of complications and disability. ${ }^{2}$

Thus, screening for hypothyroidism in newborns plays an important role. The TSH test is the best and most sensitive test for screening for congenital hypothyroidism. A second test at two weeks or two weeks after the first screening and a third infant test at 28 days may be required in premature neonates, low and very low birth weight, sick neonates, and same-sex twins. ${ }^{2}$ Several methods can be used. to take a blood sample, such as a heel skin prick, cord blood, venipuncture, or blood from a catheter. In this research, blood was taken from heel skin punctures and veins.

Management of patients with congenital hypothyroidism is by giving L-T4 (levothyroxine) drugs. Levothyroxine is given as soon as the diagnosis is established and therapy is best started before the baby is 2 weeks old. ${ }^{2}$

The initial dose of levothyroxine was $10-15 \mathrm{~g} / \mathrm{kg} / \mathrm{day}$. The next dose was adjusted according to the results of periodic TSH and FT4 examinations with an estimated dose according to age as shown in Table 4.

Levothyroxine is given orally (tablets can be crushed and mixed with drinking water). Parents should receive an explanation about how to give levothyroxine and the importance of adherence to medication. Levothyroxine can be given in the morning or evening before or with meals, provided that it is given in the same way and time every day. Giving levothyroxine should not be concurrent with giving soy milk, iron, and calcium. $^{2}$

Making therapeutic decisions if: (1) A positive screening result using filter paper (TSH $20 \mathrm{mU} / \mathrm{mL}$ ) should be confirmed with blood serum before

Table 4. Dose of L-tiroksin for Children²

\begin{tabular}{cc}
\hline Age & Dose of L-tiroksin $(\boldsymbol{\mu g} / \mathbf{k g B B} / \mathbf{h a r i})$ \\
\hline $0-3$ months & $10-15$ \\
$3-6$ months & $8-10$ \\
$6-12$ months & $6-8$ \\
$1-3$ years & $4-6$ \\
$3-10$ years & $3-4$ \\
$10-15$ years & $2-4$ \\
$>15$ years & $2-3$ \\
\hline
\end{tabular}

starting therapy. (2) Treatment should be started immediately if serum FT4 is low. (3) Doubtful laboratory results (high TSH but normal FT4) should be referred to PPK III or a specialist consultant pediatric endocrinologist for further evaluation and treatment. $^{2}$

Initial therapy with levothyroxine in the first 2 weeks of life showed significant results on neurodevelopment and in achieving intellectual outcomes in children with HK. The severity of HK was determined from T4 levels (if T4 levels $<5 \mathrm{pmol} / \mathrm{L}=$ severe, $5-<10 \mathrm{pmol} / \mathrm{L}=$ moderate, and 10-15 pmol/L = mild) and neurodevelopmental predictive factors with the severity of bone age (gene region). The absence of one or both genu epiphyses is known to be associated with 1) T4 levels at diagnosis, and 2) IQ prognosis, so it is a reliable index of intrauterine hypothyroidism. ${ }^{2}$

Monitoring of congenital hypothyroidism patients has to consider many things as listed below. (1) The dose of levothyroxine is adjusted based on the results of monitoring TSH and FT4. (2) Monitor growth: weight, length/height, head circumference until the age of 3 years, bone age, and pubertal status. (3) Development monitoring and education: 0-2 years: sensory-motor development, 2-5 years: mental and cognitive functions of language, coordination, and play, hearing and vision tests at the age of 5 years (before school), school age and beyond: attendance, academic achievement, and behavioral disorders. (4) Patient education: adherence to medication, and from high school onwards: ensuring the patient has knowledge of congenital hypothyroidism. ${ }^{11}$
This research revealed that the recall rate for screening for hypothyroidism was $1: 2024$. Pulungan et al reported that the recall rate for screening for hypothyroidism in 5 cities in Indonesia was 1:1226. Mehran et al reported that recall rates in various countries ranged from $0.01 \%$ to $13.3 \%$. Factors affecting recall rate are different screening strategies, laboratory techniques, sampling sites, iodine deficiency, human error, and the incidence of congenital hypothyroidism. ${ }^{11}$ Shajira et al reported a congenital hypothyroid recall rate of $1.98 \%$ in Bahrain using TSH sampled from cord blood. ${ }^{12}$ Another research in Asia reported various recall tests for the TSH test by means of heel blood sampling ranging from $0.37 \%$ in India, $0.69 \%$ in Sri Lanka, $2.37 \%$ in Laos, and $2.6 \%$ in Turkey. ${ }^{13-15}$ The TSH limit in this research followed the recommendations of the IAEA $(20 \mathrm{U} /$ $\mathrm{mL}$ ). Several researchers around the world use lower threshold points to detect cases that are less severe, but with an increasing number of false positives. Another disadvantage of applying a lower cutoff is the increased recall rate, effort, cost, and parental psychological distress. ${ }^{16}$

In this research, there was 1 case out of 2024 subjects with confirmed congenital hypothyroidism. The incidence rate could be compared with others, such as research by Pulungan et al, there was 1 case out of 1226 subjects. ${ }^{5}$ Researches in Sri Lanka (1:1682), India (1:6813), Laos (1:5861), Saudi Arabia (1:7175). ${ }^{13,16}$

\section{CONCLUSION}

In this research, the recall rate for congenital hypothyroidism was 1:2024. Thus, it can be concluded that the ratio of congenital hypothyroid cases in Malang 
from March to November 2020 was higher than the global ratio, which was 1:3000. The high rate of congenital hypothyroidism in Malang indicates the need for congenital hypothyroidism screening in newborns. In Malang City, screening for congenital hypothyroidism has been routinely carried out, but there were failed screening problems due to sampling error, so it did not meet the requirements for laboratory examination. Therefore, there is a need for health workers training in the sampling process. Congenital hypothyroid screening can help diagnosis the establishment of congenital hypothyroidism as early as possible and therapy can be started earlier in order to get better outcomes. Thus, screening for congenital hypothyroidism can prevent growth retardation and prevent mental retardation in children. In addition, it is necessary to provide counseling and education to parents regarding the impact and management of congenital hypothyroidism in children.

\section{FUNDING}

This article did not use sponsorship funds and purely use author funds

\section{CONFLICT OF INTEREST}

There is no conflict of interest in this article and all funding does not involve a specific sponsor or brand

\section{AUTHOR CONTRIBUTION}

In this article, all authors are involved and take part in making the article

\section{ETHICAL STATEMENT}

This article already got ethical clearance permission

\section{REFERENCES}

1. Pusat Data dan Informasi Kementerian Kesehatan RI. Situasi dan Analisis Tiroid.pdf. 2015. p. 1-8.

2. Kementerian Kesehatan R. Pedoman Skrining Hipotiroid Kongenital. Kementeri Kesehat Republik Indones. 2014;(564):1-73.

3. Samsudin M, Kumorowulan S, Supadmi S. Diagnostic Value Using Physical Indicators Compare with Gold Standard to Diagnose Suspected Cretinism among Children Under Three Years. 2014;111-24.

4. Pratama AA, Chairulfatah A, Novina N, Faisal F, Fadlyana E. Hubungan Awitan Pengobatan Hipotiroid Kongenital dengan Gangguan Perkembangan Anak di Rumah Sakit Umum Pusat Dr. Hasan Sadikin. Sari Pediatr. 2019;21(1):16. Available from: http://dx.doi. org/10.14238/sp21.1.2019.16-23

5. Pulungan $A B$, Soesanti F, Utari A, Pritayati N, Julia M, Annisa D, et al. Preliminary Study of Newborn Screening for Congenital Hypothyroidism and Congenital Adrenal Hyperplasia in Indonesia. eJournal Kedokt Indones. 2020;8(2). Available from: http:// dx.doi.org/10.23886/ejki.8.11611.

6. Riskesdas. Riset Kesehatan Dasar. Kementeri Kesehat Republik Indones. 2018;44(8):1-200. Available from: http:// arxiv.org/abs/1011.1669\%0Ahttp:// dx.doi.org/10.1088/1751 8113/44/8/085201\%0Ahttp://stacks.iop. org $/ 1751-8121 / 44 / \mathrm{i}=8 / \mathrm{a}=085201$ ? $\mathrm{key}=$ crossref. abc74c979a75846b3de48a5587bf708f

7. Cherella CE, Wassner AJ. Congenital hypothyroidism: insights into pathogenesis and treatment. Int J Pediatr Endocrinol. 2017/10/02. 2017;2017:11. Available from: https://pubmed. ncbi.nlm.nih.gov/29026407

8. Kurniawan LB. Congenital Hypothyroidism: Incidence, Etiology and Laboratory Screening. Indones J Clin Pathol Med Lab. 2020;26(3). Available from: http://dx.doi.org/10.24293/ ijcpml.v26i3.1527

9. A Adeniran K. Review Article on Congenital Hypothyroidism and Newborn Screening Program in Africa; the Present Situation and the Way Forward. I Thyroid Disord Ther. 2012;01(01). Available from: http://dx.doi. org/10.4172/2167-7948.1000102
10. Van Vliet G, Deladoëy J. Diagnosis, Treatment and Outcome of Congenital Hypothyroidism [Internet]. Paediatric Thyroidology. S. KARGER AG; 2014. p. 50-9. Available from: http://dx.doi. org/10.1159/000363155

11. Cooper S, Bowden G. Ultraviolet B Regulation of Transcription Factor Families: Roles of Nuclear Factor-kappa B (NF-\&\#954;B) and Activator Protein-1 (AP-1) in UVB-Induced Skin Carcinogenesis. Curr Cancer Drug Targets. 2007;7(4):325-34.

12. Al-Qashar F, Sobaih B, Shajira E, Al Saif S, Ahmed I, Al-Shehri H, et al. Impact of intrauterine growth restriction and birth weight on infant's early childhood neurodevelopment outcome. J Clin Neonatol. 2018;7(1):1. Available from: http://dx.doi.org/10.4103/jcn.jcn_16_17

13. Hettiarachchi $M$, Amarasena S. Indicators of newborn screening for congenital hypothyroidism in Sri Lanka: program challenges and way forward. BMC Health Serv Res. 2014;14:385. Available from: https:// pubmed.ncbi.nlm.nih.gov/25212576

14. Hoehn T, Lukacs Z, Stehn M, Mayatepek E, Philavanh K, Bounnack S. Establishment of the First Newborn Screening Program in the People's Democratic Republic of Laos. J Trop Pediatr. 2012;59(2):95-9. Available from: http:// dx.doi.org/10.1093/tropej/fms057

15. Tezel B, Dilli D, Bolat H, Sahman H, Ozbaş $\mathrm{S}$, Acican D, et al. The development and organization of newborn screening programs in Turkey. J Clin Lab Anal. 2013/12/27. 2014;28(1):63-9. Available from: https:// pubmed.ncbi.nlm.nih.gov/24375520

16. Alfadhel $\mathrm{M}, \mathrm{Al}$ Othaim $\mathrm{A}, \mathrm{Al}$ Saif $\mathrm{S}, \mathrm{Al}$ Mutairi F, Alsayed M, Rahbeeni Z, et al. Expanded Newborn Screening Program in Saudi Arabia: Incidence of screened disorders. I Paediatr Child Health. 2017;53(6):585-91. Available from: http://dx.doi.org/10.1111/jpc.13469

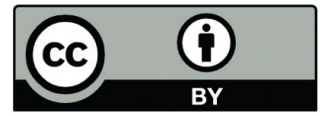

This work is licensed under a Creative Commons Attribution 